\title{
Communication Pattern and Skill of Leaders in Private University Management
}

\author{
${ }^{1}$ ANI YUNINGSIH, ${ }^{2}$ DADAN MULYANA \\ 1,2 Fakultas Ilmu Komunikasi, Universitas Islam Bandung, Jl. Tamansari No1, Bandung \\ email: ${ }^{1}$ yuningsihani@yahoo.com; ${ }^{2}$ dadanmulyana95@yahoo.com;
}

\begin{abstract}
Communication strategies and skills supported by mutually supportive management tools are one of the managerial skills that must be mastered by private university (PTS) leaders. Leadership communication skills and style will form organizational communication patterns that will become the foundation for a healthy and effective organizational climate to develop its vision and mission. This research is done by using case study method at some PTS which is representation of PTS profile in West Java. The research results indicate that communication pattern of PTS leaders is still conventional, that is following the existing organizational structure, along with some informal communication form. Leadership communication skills are diverse, and include organizational communication skills, interpersonal communication, group communication, and social communication. All types of skills are required, but there are still some skills that have not been done optimally, such as group communication skills and social communication skills.
\end{abstract}

Keywords: communication skill, communication climate, effective organization

\section{Introduction}

The managerial and organizational communication skills of higher education managers in Indonesia, particularly among private universities (PTS), often receive less attention. Figures who became the manager of universities in the PTS, generally are some of figures of the lecturers who may be previously not be prepared or not prepare to become a leader or manager in PTS. Those who are elected may initially concentrate more on developing a functional career as a lecturer, not as a structural official or as a leader for an educational institution where he works as a lecturer.

Such general conditions lead to communication patterns and leadership skills of the PTS which usually less conducive and poorly honed. Informative, integrative, regulative and persuasive functions of organizational communication often do not run optimally and caused other management functions run stagnant.
Meanwhile, the leaders and managers of PTS now face very complex challenges as well as the quite tight and more open competition in the era of internationalization, especially through the agreement of the ASEAN Economic Community. The capacity of manager in private university (PTS) is expected to have a unique ability to synergize their potential capacity with their partner potential, in order to achieve the institution's vision.

The correct communication strategy and organizational communication pattern, supported by mutually supportive communication patterns, is one of the managerial skills that must be mastered by the private university (PTS) leaders. Ongoing communication, both internally and externally, will open up teamwork opportunities in running the college's principles of Tridharma. Based on interviews with one of the staffs in Kopertis (private university coordination) of Region IV, in some cases of problematic universities, after tracing, it was rooted from the lack of a

Received: October 27, 2016, Revision: April 20, 2017, Accepted: May 19, 2017

Print ISSN: 0215-8175; Online ISSN: 2303-2499.

Accredited by DIKTI. SK Kemendikbud, No.040/P/2014, valid 18-02-2014 until 18-02-2019, Indexed by DOAJ 
harmonious communication pattern between the PTS managers and the managers of the foundation that overshadowed the PTS. In addition, there is also the lack of effective communication between PTS and Kopertis management as an extension institution of the Directorate of Higher Education, which carries out the supervision, control and supervision of the PTS (interview with Udansyah in 2015).

Referring to the background, a more indepth analysis of leadership's communication skills and skill in PTS management is required. Based on the results of research conducted in 2015 (Mulyana et al, 2015) and 2016 (Mulyana\&Yuningsih, 2016) that studied about private universities in West Java, which is a representation of PTS population in West Java. The study is about the pattern of PTS organizational communication internally, and external communication between PTS with Kopertis, which obtained an overview of the actual condition of communication patterns and skills of the PTS leaders, which then led researchers to analyze and provide recommendations for organizational communication patterns that are more suited to the demands and needs to become a healthy, accountable and reputable higher education. The result of this study also raises the actual issues about the limited capacity and communication skills of the PTS managers in West Java, which need to be studied further.

Inadequate intelligence of interpersonal communication, coupled with a less conductive communication pattern, may cause the PTS managers and their respective academicians to be trapped in perspective partially, and trapped in a comfort zone that prioritizes the stability of routine administrative activities, rather than the transactional communication process, positional and transformational which is a necessity for the fulfillment of the demands and need for a qualified higher education.

Based on the results of the research, there are 3 (three) identification problems that will be analyzed in this paper, namely: first, how the pattern of organizational communication built PTS internally and externally in performing the tridharma function of university. Secondly, how does the communication skills profile of PTS leadership in carrying out healthy, accountable and reputable management. Third, what factors are inhibiting the supervision, control and supervision of PTS by Kopertis.

\section{Organizational Communication Pattern}

Organizational communication is an organizing behavior that occurs and how it involved in the transaction process and give meaning to what happens (Pace \&Faules, 2001: 31-33). There are several perceptions of organizational communication from some experts, namely Perceptions of Redding and Saborn, as well as Perceptions of Zelko and Dance (in Pace \& Faules, 2001).

Redding and Saborn said that organizational communication,

is sending and receiving information in complex organizations. Included in this field are internal communications, human relationships, organizational unity relationships, downward communications or communications from superiors to subordinates, upward communications or communications from subordinates to superiors, horizontal communication or communication from persons of equal level within the organization, communication skills and speaking, listening, writing and communication program evaluation.

Zelko and Dance said that organizational communication is an interdependent system that includes internal and external communication. Internal communication is communication within the organization itself, such as communication from subordinates to superiors, communication from superiors to subordinates, and communication of the same-level fellow employees. While external communication is communication that the organization conducts to the outside environment, such as communication in product sales, advertising, and relationships with the general public.

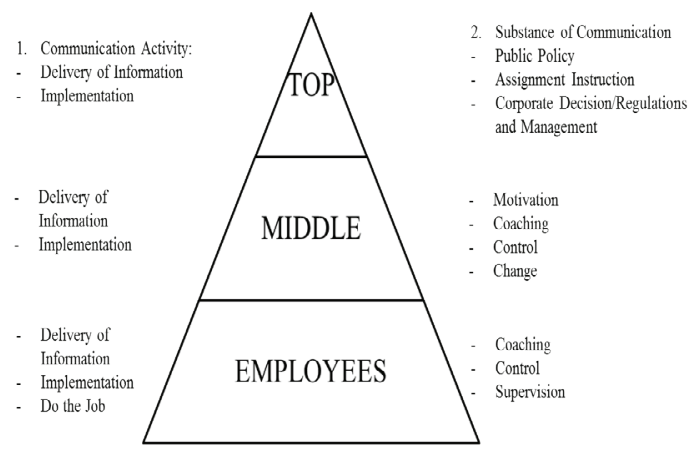

Figure 1. Pattern of Communication Strategy and Implementation of Management Function in an Organization

Source: Ruslan(2002:88)

From the above explanation, it can be 
concluded that organizational communication is a process that happens in the organization. The communication process that occurs is divided into 4 (four) aspects, namely: downward communication, upward communication, horizontal communication, and cross-channel communication.

The pattern of organizational communication is a set of behavior and communication rituals run by all members of the organization from the highest level of leaders to the lowest level of employees. Organizational communication patterns can formally refer to Figure 1.

\section{Interpersonal Communication Skills}

Among the most important communication skills that need to be honed and improved are interpersonal communication skills. Interpersonal communication skills is the ability to build good relationships with others on a continuous basis, over a relatively long period of time, and resulting in mutually beneficial cooperation.

In addition to interpersonal skills, there is an interpersonal intelligence that a leader must possess, namely the ability to observe and understand the intentions, motivations and feelings of others. A leader has to be sensitive to the facial expression, voice and other body movements of others and able to respond effectively in communicating. This intelligence is also able to help understand the world of others, their views, and attitudes which generally can lead the group.

People with low interpersonal intelligence can generate interpersonal conflict, as well as wider conflict. This is confirmed by Sullivan in Chaplin (2000: 257) that mental illness and personality development are primarily determined more by interpersonal interaction than by constitutional factors.

\section{Conversation Intelligence}

Interpersonal intelligence is generally built through conversational skills. For a leader, the ability to engage in conversation affects his effectiveness in becoming a transformational leader.

According to Judith E. Glaser (1941), Conversational Intelligence (CI) can be developed at the organizational, team, and individual levels. At the organizational level, CI is the ability of an organization to communicate in ways that can create a concept of shared reality. At an individual level, $\mathrm{CI}$ is an all-human ability to connect, cooperate, and navigate with others. CI is a collaborative effort. The more often it is used together, the more CI will increase.

According to Glaser, to raise our CI to the highest level of Transformational Intelligence (TI), we need to become master and creator of conversation rituals that make it possible for us to express ideas, feelings, hunches, thoughts, and aspirations.

With a transformational CI, then if there is a dissent, it will be smaller or even disappear altogether. Thus, according to Glaser, CI at the transformational level can result in improved management functions and create a framework for improving relations and cooperation, releasing new energy for growth and transformation.

\section{Organizational effectiveness}

According to Miller (1977, in Siagian 1986: 33) that:

"Effectiveness can be defined as the degree to wich a social system achieves its goals. Effectiveness must be distinguished from efficiency. Efficiency is mainly concerned with goal attainments." (Efficiency primarily contains a sense of comparison between cost and outcome, whereas effectiveness is directly linked to the achievement of an objective.)

Furthermore, it is said by Georgopualos and Tannebaum (in Etzioni, 1969: 82) that:

\begin{abstract}
".....organization effectiveness as the extent to which an organization as a social system, given certain resources and mean, fulfill its objective without incapacitating its means and resources and without placing strain upon its members." (The view may be interpreted that organizational effectiveness is the degree to which an organization as a social system with all available resources and facilities meeting its objectives without wasting and avoiding unnecessary tension among the members).
\end{abstract}

Argris discusses how to achieve the level of effectiveness (Argyris, 1964) which says: "Organizational effectiveness then is a balanced organization with optimum emphasis upon achieving object, solving competency, and human energy utilization". (Organizational effectiveness is a balance or an optimal approach to the achievement of objectives, capabilities and utilization of human labor).

\section{Organizational Communication Barrier}

According to Prof. Onong Uchjana Effendy, MA, in his book of Science, Theory, and Philosophy of Communication 
(Effendy, 2003), there are 4 (four) types of communication barriers, namely disturbances, interests, latent motivations and prejudices.

There are 2 (two) types of interruptions to the course of communication based on its nature, which can be classified as mechanical and semantic disturbances. Mechanical disturbance, i.e, disturbances caused by communication channels or physical noise. Meanwhile, semantic disorder is the interference associated with communication messages which turn the understanding into misunderstanding (corrupted).

Meanwhile, the latent motivations and interest factors will make a person selective in responding or experiencing a message. Latent motivation will encourage someone to do something based on their wants, needs, and shortcomings. The more appropriate communication with a person's motivation, the greater the likelihood that the communication would be received properly by the parties concerned. Otherwise, if the communication is not in accordance with the motivation of the communicant, it will be ignored.

The prejudice factor is one of the major obstacles or barriers to effective communication. People who have prejudices will be suspicious and oppose communicators who want to launch communication.

\section{PTS as a Learning Organization}

Senge (1990) underlined that a successful learning organization is indicated by the following characteristics: the individual learning process works well; knowledge sharing process works well; corporate culture supports learning processes and activities; employees are motivated and fully supported to be able to think critically and dare to take risks on innovation and new ideas which he runs; and the organization holds that employees have an important contribution to the organization progress.

"Learning Organization are organizations where people continually expand their capacity to create the result they truly desire, where new and expansive patterns of thinking are nurtured, where collective aspiration is set free, and where people are continually learning to see the whole together" (Senge, 1990). So that organizations are not only required to adapt to changes but also demanded to be able to create new knowledge to reach the future. "The learning organization seems to work on the assumption that "learning" is valuable, continuous, and most effective when shared and that every experience is an opportunity to learn" (Kerka, 1995).

A university that seeks opportunities in future global competition is those who continuously strive to improve the quality of inputs and processes to produce outputs that the market receives (Muhardi, 2000). Healthy organizations allow universities to run their activities according to their vision and mission, and meet the needs of stakeholders (Kusmiati, 2015). Therefore, universities are required to be able to create new innovations in the sustainability of their organizations, and to provide accountability regarding the implementation and implementation of its mission and functions to its stakeholders.

\section{Method}

This study uses case study method to observe, elaborate, and explore the informants who are managers of private universities in West Java. The informants are six managers from different PTS, and they are organizational communication actors, both internally and externally. For triangulation data, informants from Kopertis Region IV, West Java-Banten, also being interviewed.

The data collection techniques are analyzed in several ways, namely: in-depth interviews conducted to 6 (six) informants from private universities in West Java and Banten, and also to 3 (three) informants from Kopertis region of West Java And Banten; Focus Group Discussion, attended by PTS managers, and Kopertis leaders related to planning and implementing organizational communication; Literature study, collecting data and information from books, documents, files, and other written sources related to organizational communication.

Processing and analysis of research data is done by: (1) data reduction, that is choosing and sorting the relevant data and set aside the irrelevant or less relevant data; (2) categorization and tabulation of data, that is grouping similar data to answer research question; (3) interpretation and analysis data, ie giving meaning and analyzing data to make second degree construction into model or picture which is a research finding, then analyze it by using theoretical framework as reference; (4) drawing conclusions and formulation of recommendations from research results, which is the result of thought to be implemented in practical and used as 
a reference for scientific development in subsequent research.

\section{Pattern, Profile Skills and Organiza- tional Communication Obstacles}

The result of research on communication pattern and leadership communication skill in PTS management in West Java refers to research question which become the focus of this research study, and can be described in the form of model which is the finding of actual condition in the field, interpretation, and discussion which refers to the theory and concept - relevant organizational communication concepts. Model and interpretation of research results can be described as follows:

First, the pattern of organizational communication built by the PTS internally and externally in carrying out the tridharma function of the university, which is generally done by the PTS leaders both internally and externally. It can be illustrated through the model as follows:

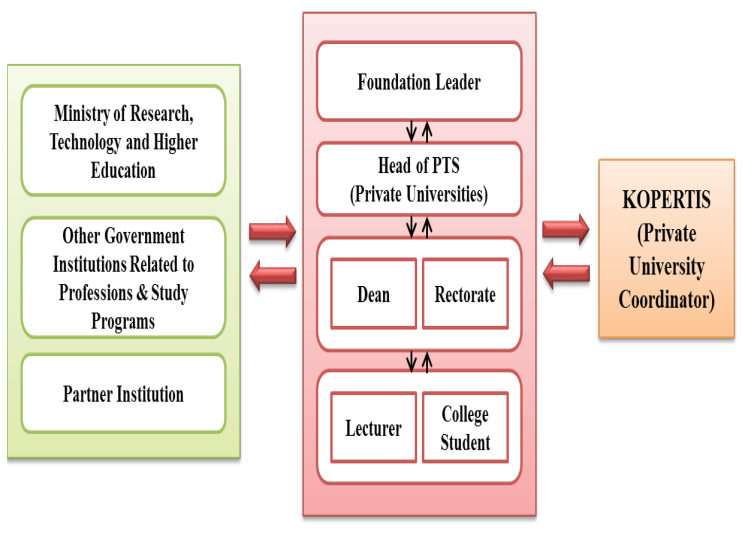

Figure 2. Organizational Communication Pattern Built by PTS Internally \& Externally in Running Tridharma Function of Higher Education

Source : Research Result (2016)

Internally, the leaders organizational communication pattern consists of upward vertical communication with the foundation leaders in the form of coordination, consultation, and audience to convey various information and policies to be applied. Formal communication patterns follow the structure and legality applicable in the university concerned, but informally there are variations of communication patterns conducted by the PTS management. Among others, there are interpersonal communication at certain events held at the university level, on occasions that often arise between internal and external meetings, which are attended by structural officials at the foundation and university levels.

The downward vertical communication, formally carried out by leaders of private universities through leader meetings held regularly or incidentally, which includes other structural officials under the rector, as well as official deans in the university environment. Besides formal communication, informal communication is often done, both to the structural officials and to the academicians, lecturers, students and education personnel in the university environment. Informal communication can be done on any occasion, especially in events attended by the PTS leaders. In addition, the academic community also has the opportunity to communicate directly with the leaders of PTS through hearings or interpersonal face-to-face communication on various occasions, both planned and spontaneous.

The external communication pattern of the private university leaders to build international cooperation is conducted in several ways, among others: (a) Responding to letters or invitations from relevant government institutions, such as KemenristekDikti, other government institutions related to professions and study programs, partner institutions and Kopertis; (b) Sending delegates to attend meetings or dissemination of relevant institutions; (c) Conducting hearings with the central and regional governments related to the professions and courses; (d) Conducting proactive communication with Kopertis to optimize the function of the college tridharma functions; and (e) Conduct visits to cooperate with other universities in the academic field.

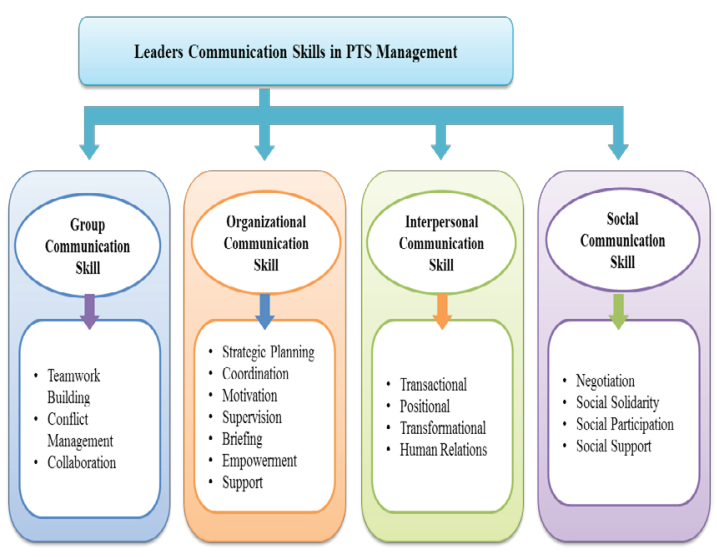

Figure 3. Communication Skill of PTS Management in Running Healthy, Accountable and Reputable Management

Source: Research Result (2016) 
Second, the communication skills profile of the PTS leaders in carrying out healthy, accountable and reputable management. The result of the research shows that there are 4 (four) categories of communication skills practiced by PTS management: first, organizational communication skill; Second, group communication skills to build team of effectiveness and conflict management; Third, interpersonal communication skills in building relationships to maintain a conducive organizational climate; And finally, social communication skills. Overall, the categorization of communication skills can be illustrated in Figure 3.

The organizational communication skills contained in the organizational context should be attached to the private university leaders as policy makers, as well as the managers of the university function and operation, which become the driving force of a university. Of course, the communication skills of the PTS management are vary, both in competence, and in the style of producing and processing messages of organizational communication. Every university has different degree of complexity of organizational communication, depends on the size of the university, as well as the number of courses and students it manages. Similarly, at each level of university managers, there will be different challenges to their communication skills, in accordance with their responsibilities and respective duties.

Based on the research, there are 4 (four) categories of communication skills practiced by the head of private universities in West Java. First, group communication skills, which include skills to build compact and loyal teamwork, skills to manage internal conflicts, and communication skills to build and enhance collaboration among various resources within the university.

Second, organizational communication skills that include communication skills in developing planning and achieving the vision strategy of the university's mission; coordinating skills; motivate the entire academic community; supervise academic functions, student affairs, finance and cooperation functions; skill to direct and empower human resources and facilities; As well as skills to provide support for subordinate initiatives.

Third, interpersonal communication skills include the skills of conducting transactional approaches to build relationships; skills to position themselves in relevant conditions and contexts; skills of self-change and others in accordance with performance demands, and human relations skills to build a conducive atmosphere and working climate.

Fourth, social communication skills, namely the ability to communicate with social groups (community, professional associations, college associations, etc.) existing in the internal and external environment, such as negotiation skills; skills to build commitment and cohesiveness; and skills to demonstrate support and participation in social activities relevant to the duties of the PTS management.

Fifth, the inhibitors of supervision, control and supervision of PTS by Kopertis include 4 (four) main factors, which can be described as follows:

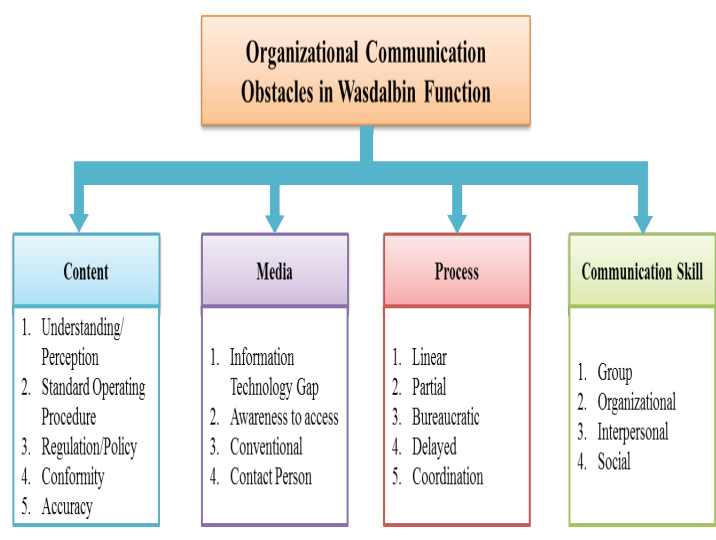

Figure 4. Organizational Communication Obstacles in Wasdalbin Function

Source: Research Result(2016)

The first factor of communication barrier is the communication content, ie messages and packaging messages sent by PTS management to Kopertis, either internally or externally, which consist of: a lack of understanding and proper perception of the message being sent; unclear and decisive communication procedures; regulations or policies that change frequently but the process of socialization and implementation are not in line; conformity between information submitted with information required immediately by each party; and finally the accuracy of message packaging which considered not in accordance with the psychological conditions of institutional managers.

The second factor that becomes the communication barrier is the communication medium. The media used to communicate between the PTS administrators with Kopertis, internally and externally, is still considered to have gaps, especially in terms of IT-based media (online media) because there are 
still many private universities in West Java and Banten which are left behind in IT. In addition, the awareness of PTS management to access Kopertis media proactively is still low. Conventional media is still dominantly used, so the speed of communication is still not adequate, both internally and externally. Finally, the contact person of PTS management in Kopertis is considered unclear and often changed and making it difficult to communicate regularly about certain areas. Since the contact person in PTS management is considered less credible in the eyes of Kopertis, so that communication and information are often delayed and out of target. Information from Kopertis often does not spread widely to the academic community, or to the competent authority of the private university concerned.

A third factor inhibiting communication is the process of communication, which is still seen as linear, one-way, and few opportunities for direct interaction. Message flow is considered to be partially not well integrated, too bureaucratic, and resulted in the number of messages or information delayed and then delay in receiving by each PTS management from and to Kopertis.

The fourth factor that becomes the communication barrier in wasdalbin (monitoring, controlling, and maintaining) function is communication skill attached to the PTS and Kopertis managers. These communication skills include group communication skills, organizational communication, interpersonal communication, and social communication that are considered inadequate. In addition, media literacy and IT capacity owned by PTS are also considered to be improved.

\section{Pattern Interpretations, Skills Profile, and Organizational Communication Obstacles}

The organizational communication pattern is a set of communication behaviors and rituals performed by all members of the organization from the highest level of leaders to the lowest level of employees. The pattern of organizational communication is largely determined by the communication pattern of the organization's leadership. Formal and informal communication patterns intertwine with the rhythm and flow that is controlled by organizational managers. The same thing applied in PTS organizations. Leadership communication patterns determine the direction, flow and communication behavior, both formally and informally. The communication pattern and formal communication network conducted by PTS leaders, has referred to the ideal communication pattern proposed by Ruslan (2002: 88), although in practice there are still some communication paths that jumped or choked. As for the pattern of informal communication, there is generally a lot of grapevine, which is the flow of communication messages that propagate like wine in all directions, if it is not controlled it can burden or inhibit the flow of formal communication and make the organization less effective. Argris suggested that to achieve the optimum level of effectiveness requires a balance between the optimal (communication) approach, on achieving the objectives, capability and utilization of available manpower (Argyris, 1964).

The communication skills profile of the PTS leaders in carrying out healthy, accountable and reputable management indicates the existence of various skills required in various communication contexts. Despite the main organizational communication skills, other skills such as interpersonal, group, and social communication need to be owned by the PTS management. Social communication skills are required by PTS management since it is not an organization that operates in a vacuum, but needs to socially interact with the surrounding environment. There is still a strong cultural aspects and local wisdom in PTS organization itself, which requires group communication skills and interpersonal communication.

The inhibitors of supervision, control and guidance of PTS by Kopertis, are generally due to the interpretation and understanding of the message content and information technology constraints that have not been optimally utilized. The Kopertis itself has been trying to build a communication system and services based on-line, but on the other hand, there are many cultural communications of PTS which is not based on-line. There are still many PTS managers and university lecturers who are not accustomed to communication based on-line.

Therefore, one of the obstacles of organizational communication in performing the wasdalbin function is the communication skills of PTS managers. According to Glaser, transformational personal communication skills begin beginning with the trust between 
leader and his subordinates. In the relationship between a leader and his subordinates, it is important that the relationship is based on the mutual trust between them. To gain the trust of his subordinates, a leader must have credibility in the eyes of his subordinates. One source of credibility of a leader is that he does what he says (walk the talk). If the good things he said is not done in his daily behavior, the leader will lose the credibility in the eyes of his subordinates.

\section{Conclusions}

Internal and external organizational communication pattern has been built by PTS to perform the university's Tridharma function, formally and informally. The formal communication pattern follows the existing organizational structure, while the informal communication pattern follows unique culture and local wisdom and applies differently in each PTS.

Communication skill profile of PTS leaders is applied in carrying out healthy, accountable and reputable management. The skills of the PTS management in running the management are generally adequate, but other skills in the context of interpersonal communication and social communication are often still not received serious attention. Social communication skills are needed because PTS is not an organization operating in a vacuum, but socially have to interact with the surrounding environment. Interpersonal communication skills are needed due to the strong local culture in West Java that affects the communications climate within the PTS, where the local culture still demands personal approaches in solving management problems.

Inhibitors of supervision, control and supervision of PTS by Kopertis generally caused by interpretation and understanding the message content and information technology constraints that have not been utilized optimally. While Kopertis itself has been trying to build a communication system and services based on-line, but on the other hand, many cultural communications in PTS are not based on-line. There are still many PTS managers and university lecturers who are not accustomed to communication based on-line.

\section{References}

Argyris. (1964). Organizational Leadership dan Participation Management. The Journal of Business. Vol. XXVII (January): 1-7.

Chaplin, J.P. (2000). KamusLengkapPsikologi (terjemahanKartono, K). Jakarta: Raja GrafindoPersada.

Effendy, O.U. (2003). Ilmu Teori \& Filsafat Komunikasi. Bandung: Citra Aditya Bakti.

Etzioni, A. (1961). A Comparative Analysis of Complex Organizations: On Power, Invovement, and Their Correlates, The Free Press of Glencoe, Inc.

Glaser, J.E. (2016). "Build Trust Through Conventional Intelligence". http://www. creatingwe.com/articles/716-buildtrust-trough-conversational-intelligence, diaksestanggal 1 September 2016

Kerka, S. (1995). Organisasi Pembelajaran: Mitos dan Realitas. Eric Clearinghouse. http://www. cete.org/acve/docgen. asp? $t$ tbl=archive\& $I D=A 208$

Kusmiati, M. (2015). Membangun Kesehatan Organisasi Institusi Pendidikan Dokter: Sebuah Transformasi Menuju Akuntabilitas Sosial. Jurnal MIMBAR Vol 31, No 10, Juni 2015.

Muhardi. (2000). Keterpaduan Unsur Lembaga, Dosen dan Mahasiswa Pada Perguruan Tinggi.Jurnal MIMBAR Volume 16, No. 1, Tahun 2000.

Mulyana D. , Et.al. (2015). Hubungan Iklim Organisasi Kopertis dengan Kepuasan Kerja Dosen. Laporan Penelitian Hibah Bersaing DIKTI.

Mulyana, Dadan, and Ani Yuningsih. (2016). Pola Komunikasi Organisasional Kopertis. Laporan Penelitian Hibah Bersaing DIKTI.

Pace Wayne R, Faules F. Don. (2001). Komunikasi Organisasi Strategi Meningkatkan Kinerja Perusahaan. Bandung: PT. RemajaRosdakarya.

Ruslan, R. (2002). Manajemen Humas dan Komunikasi, Konsepsi, dan Aplikasi. Jakarta: PT. Raja GrafindoPersada.

Senge, P. (1990). The Fith Dicipline. Double day: USA

Siagian, S. P. (1986). "Organisasi, Kepemimpinan dan Perilaku Administrasi". Jakarta: PT. Gunung Agung. 